Journal of Applied Pharmaceutical Science Vol. 6 (02), pp. 141-145, February, 2016

Available online at http://www.japsonline.com

DOI: $10.7324 / J A P S .2016 .60222$

ISSN 2231-3354 (cc)) BY-NC-SA

\title{
Pharmacogenomics: Knowledge, Attitude and Practice among Future Doctors and Pharmacists-A Pilot Study
}

\author{
Adamu Yau, Mainul Haque* \\ Unit of Pharmacology, Faculty of Medicine, Universiti Sultan Zainal Abidin, Medical Campus, Jalan Sultan Mahmud, 20400 Kuala Terengganu, Malaysia.
}

\begin{tabular}{|c|c|}
\hline ARTICLE INFO & ABSTRACT \\
\hline Article history: & \multirow{7}{*}{$\begin{array}{l}\text { Rational application of genomics into practice would lead to safer chemotherapy through individualized } \\
\text { medicine. The increasing trends of genetic discoveries coupled with increased adoption of pharmacogenomics in } \\
\text { developed countries pose challenges to the presence and future healthcare professionals, not only in Malaysia. } \\
\text { This research, aimed to assess knowledge, attitude and practice of final-year future healthcare professionals } \\
\text { towards pharmacogenomics. A cross-sectional study was conducted by administering self-completed } \\
\text { questionnaire (Reliability } 0.82) \text { to } 247 \text { participants, among which } 68.4 \% \text { responded. More than half were female } \\
\text { medical students. The mean knowledge scores in percentage were } 57.57 \pm 20.2 \text { with a significant difference } \\
\text { between the two groups }(\mathrm{p}=0.002) \text {. Positive attitude, but low practice were observed which differs between } \\
\text { pharmacy and medical students, p }<0.05 \text {. Association between knowledge, attitude and practice, were } \\
\text { investigated. The majority has demonstrated good knowledge and attitude towards pharmacogenomics, but with } \\
\text { low practice. Studies are reguired to large sample and to examine barriers to adoption of pharmacogenomics. }\end{array}$} \\
\hline Received on: $27 / 12 / 2015$ & \\
\hline Revised on: 15/01/2016 & \\
\hline Accepted on: 28/01/2016 & \\
\hline Available online: $27 / 02 / 2016$ & \\
\hline Key words: & \\
\hline $\begin{array}{l}\text { Pharmacogenomics, future } \\
\text { healthcare professionals, } \\
\text { KAP. }\end{array}$ & \\
\hline
\end{tabular}

\section{INTRODUCTION}

Adverse Drug Reactions (ADRs) is responsible for a significant number of hospital admissions ranging from $0.3 \%$ to 11\% (Jeetu and Anusha, 2010; WHO, 2002; Islam et al., 2014b). Pharmacogenomics (PG) is the study of how individual genetic makeup influences the response to a therapeutic intervention. The marked increase in the cases of ADRs involving drugs known to be metabolize, transport and or affected by genetic polymorphism and the fact that only about $60 \%$ of the patients respond adequately to the available drugs (Sadee, 2011), with or without ADRs called for an urgent implementation of PG into Practice. In addition, a lot of developments have been made in the field of PG over six decades, and its promising roles in ADRs, drugs safety and efficacy. However, the practical application of PG has been below expectation (Bannur et al., 2014; de Denus et al., 2013). In general, PG is not yet seen as an essential tool in drug safety, therefore not an important

* Corresponding Author

Prof. Mainul Haque, Unit of Pharmacology, Faculty of Medicine,

Universiti Sultan Zainal Abidin, Medical Campus, Jalan Sultan

Mahmud, 20400 Kuala Terengganu, Malaysia.

Email: runurono@gmail.com component of routine medical practice. Several studies reported the knowledge and practice gap, lack of formal training and awareness toward PG among current Physicians and pharmacists (Yau et al., 2015a; Bannur et al., 2014; Stanek et al., 2012; Johansen Taber and Press, 2014; Yau et al., 2015b). In all cases, less attention has been paid to future Doctors and Pharmacists despite their reported knowledge gap on PG (Filiptsova et al., 2015; Moen and Lamba, 2013). This research for the first time would assess Knowledge, attitude and practice (KAP) towards PG among Malaysian Medical and Pharmacy students for possible educational and concrete recommendations.

\section{MATARIALS and METHODS}

A cross-sectional pilot study of final-year pharmacy and medical students was conducted using a valid and reliable survey instrument. The questionnaire and the informed consent were distributed to the participants via face to face at their respective schools. The questionnaire development, validation and psychometric analysis were explained and published in another article (Yau et al., 2015c). The study was conducted at one of the four randomly selected Malaysia universities. This article reported only the PG part of the pilot the study. 
The population involved registered Final-year Medical and Pharmacy students sampled from faculty of Pharmacy and faculty of medicine of Universiti Sains Malaysia (USM). Only those interested to participate in the study (with informed consent) were included, while for exclusion criteria involved final year Medical or Pharmacy students that participated in the face validity and reliability studies, and or those decided not to participate by disagreeing in the consent form. The sample size was calculated with formula using these variables: $\mathrm{Z}=$ critical value (reliability coefficient $)=1.9, \mathrm{p}=$ power $=80 \%, \mathrm{~d}=$ acceptable error $(0.05 \%)$ and $n=$ sample size, and $n$ (sample size) was found to be 247 after adding 7\% drop out (Charan, and Biswas, 2013). Therefore, this study was conducted on 247 final-year medical and pharmacy students to assess their level of KAP towards PG in drug safety. Study Location: This pilot study was conducted at USM: established as the second university in the country in 1969, USM was first known as Universiti Pulau Pinang. According to their website in 2015, there are approximately 30,000 students at its 17 Academic Schools on the main campus in the island of Penang; 6 Schools at the Engineering Campus in Nibong Tebal (approximately $50 \mathrm{~km}$ from the main campus); and 3 at the Health Campus in Kubang Kerian, Kelantan state of Malaysia (approximately $300 \mathrm{~km}$ from the main campus). Data Analysis: The data were statistically analyzed using version 20.0 of the statistical Package for Social Sciences (IBM® SPSS®) for Windows. Descriptive statistics was used in representing the respondents' demographic information. The Pearson Chi-Square test was used for determining differences between categorical variables (Steve, 1998). The analysis for the continued variables was done using the independent/student t-test and one-way ANOVA with Post Hoc Tukey HSD (honestly significant difference) were used where the F statistic was significant and presented as a mean and standard deviation. For skewed data if $25 \%$ or more of the cells in the table have expected frequencies of less than 5, or if any expected frequency is less than 1, Fisher Exact test was preferred over the chi-square test (Field, 2009; Hinton, 2014; Pallant, 2013). The level of significant was considered at $\mathrm{p}<0.05$. Ethical Approval: The study has been reviewed by the Universiti Sultan Zainal Abidin (UniSZA) and UHREC (UniSZA Human Research Ethics Committee) and granted approval with reference number: UniSZA.N /1/628- (69) dated $21^{\text {st }}$ July, $2014 \quad\left(23^{\text {rd }}\right.$ Ramadhan 1435H $)$ before commencement of the research. Permission to approach the students was officially obtained from the Deans of their respective faculties. All Participants were briefed on the researcher physically. All the participants were given and had signed the informed written consent form before participating in the study.

\section{RESULTS}

A response rate of $68.4 \%(n=169)$ was recorded, six incomplete responses were excluded. The respondents' characteristics, the majority were medical students and female students accounting for $63.3 \%$ and $69.85 \%$ respectively, with a significant ( $\mathrm{p}=0.001$ at $\alpha=0.05$ ) difference between the professions (Table 1). The mean age of the respondents was $22.98 \pm 1.03$ years old, with pharmacy students $(22.03 \pm 0.44)$ younger than the medics students $(23.53 \pm 0.85)$ at $\mathrm{p}$-value $=0.001$. The majority $(52.7 \%)$ of the respondents were Malay, followed by Chinese $(37.9 \%)$, then Indian $(7.7 \%)$, Bumiputra $(1.2 \%)$ and others $(0.6 \%)(\mathrm{p}=0.080)$. "The association between demographic information and mean KAP scores among the respondents (Table 2)": There are statistically significant differences for knowledge scores gender, age and professions: Pharmacy students have higher mean knowledge score 9.23 \pm 2.02 against medical students $7.38 \pm 3.00$ with $t$ and $p$-value of 18.485 and $<0.005$ respectively. In terms of gender, females demonstrated higher mean knowledge score $8.73 \pm 2.90$ compared to $7.77 \pm 2.75$ for males students with $p$ value $<0.001$ and $t=4.150$. For the age of the participants, $21-22$ years old have higher mean knowledge scores of 9.18 \pm 2.02 , followed by $23-24$ years old category with $7.45 \pm 3.01$, and $25-26$ years old with $7.14 \pm 3.15$, with $\mathrm{p}=0.008$. The mean attitude score was same across the professions, gender and age of the respondents. The mean attitude score of Pharmacy students was $(27.77 \pm 3.61)$ and that of Medical students $(26.22 \pm 3.33)$ with no statistical significant $F$ and p-values of 21.83 and 0.367 respectively. Females demonstrated high mean attitude score of $26.40 \pm 3.71$ against $25.57 \pm 3.44$ of males, with $\mathrm{f}$-value $=1.9$ and $p$ $=0.170$, which is statistically not significant at $\alpha=0.05$. Across the age range of the respondents, 21-22years old have more attitude towards PG $(27.66 \pm 3.62$, followed by 26-26 years old participants $(26.15 \pm 4.11)$ and then $23-24$ years old $(25.19 \pm 3.26)$, with F-value $=9.476$ and $\mathrm{p}<0.001$, which is statistically significant at alpha level of 0.05 . The practice among the respondents varies with age and professions, but not with gender. The practice level of pharmacy students $(16.45 \pm 4.29)$ is higher than that of medical students $(10.74 \pm 3.69)$, with $\mathrm{t}$-value $=83.196$ and $\mathrm{p}<0.001$ at $95 \%$ level of significant. The level of practice for males is $12.59 \pm 5.10$ which is very similar to that of female $(12.94 \pm 4.67)$, with $\mathrm{t}$-value $=$ 0.192 and $p$-value $=0.662$ at an alpha level of 0.05 . The exposure of the participants towards PG, it can be seen that, all of the pharmacy students do ask information about ADRs at least one time in their program while $93.46 \%$ of medical students do (Table 3). Also $91.94 \%$ of pharmacy students have had attended lecture that was associated with effects of genetic variations on drug therapy during their study period, against $57.01 \%$ of medical students that ever had. In addition, about half (47.66\%) of medical students have never related genetic variation to ADRs, while only $8.06 \%$ of pharmacy students that have never do. Moreover, more than two third $(69.16 \%)$ of the medical students have never employed the idea of human genetic variation when trying to solve a given drug-related case study questions, while only about onethird $(38.71 \%)$ of pharmacy students that have never had. In term of updating the PG knowledge, about half (45.79\%) of medical students have never updated my knowledge on genetic information in relation to drugs, in contrast to only $19.35 \%$ of pharmacy students that have never updated their knowledge of PG. 
Table 1: Demographics of Respondents.

\begin{tabular}{|c|c|c|c|c|c|c|c|}
\hline \multirow[t]{2}{*}{ Personal characteristics } & \multicolumn{2}{|c|}{$\begin{array}{l}\text { Pharmacy Students } \\
(\mathbf{N}=62)\end{array}$} & \multicolumn{2}{|c|}{$\begin{array}{l}\text { Medical Students } \\
\quad(\mathbf{N}=\mathbf{1 0 7})\end{array}$} & \multicolumn{2}{|c|}{$\begin{array}{l}\text { Total } \\
\text { (N169) }\end{array}$} & \multirow[t]{2}{*}{ p-value } \\
\hline & $\mathbf{N}$ & $(36.69) \%$ & $\mathbf{N}$ & $63.31 \%$ & $\mathbf{N}$ & $100 \%$ & \\
\hline \multicolumn{8}{|l|}{ Gender } \\
\hline Male & 11 & 6.5 & 40 & 23.7 & 51 & 30.2 & $X^{2}=21.35$ \\
\hline Female & 51 & 30.2 & 67 & 39.6 & 118 & 69.8 & $\mathrm{p}=0.005^{*}$ \\
\hline \multicolumn{8}{|l|}{ Age group } \\
\hline $21-22$ & 60 & 35.5 & 2 & 1.2 & 62 & 36.7 & $\mathrm{X}^{2}=152.41$ \\
\hline $23-24$ & 1 & 0.6 & 92 & 54.4 & 93 & 55 & $\mathrm{p}<0.001 *$ \\
\hline $25-26$ & 1 & 0.6 & 13 & 7.7 & 14 & 8.3 & \\
\hline \multicolumn{8}{|l|}{ Ethnicity } \\
\hline Malay & 37 & 21.9 & 52 & 30.8 & 89 & 52.7 & \\
\hline Chinese & 24 & 14.2 & 40 & 23.7 & 64 & 37.9 & $X^{2}=7.178$ \\
\hline India & 1 & 0.6 & 12 & 7.1 & 13 & 7.7 & $\mathrm{p}=0.08$ \\
\hline Bumiputra & 1 & 0.6 & 2 & 1.2 & 2 & 1.2 & \\
\hline Others & 0 & 0.0 & 1 & 0.6 & 1 & 0.6 & \\
\hline
\end{tabular}

Chi-square with Fischer Exact test statistic significant at 0.05 level+

Table 2: KAP Scores of Respondents Towards PG with Some Selected Demographic Variables.

\begin{tabular}{|c|c|c|c|c|c|c|c|c|c|c|}
\hline & \multicolumn{3}{|c|}{ Total Knowledge score } & \multicolumn{2}{|c|}{ Total Attitude Score } & \multicolumn{3}{|c|}{ Total Practice Score } & \multirow[b]{2}{*}{ F-Stat } & \multirow[b]{2}{*}{ p-Value } \\
\hline Variables & $\mathbf{N}$ & Mean \pm SD & F-stats. & P value & Mean \pm SD & F-stats & P value & Mean \pm SD & & \\
\hline \multicolumn{11}{|l|}{ Discipline } \\
\hline Pharmacy & 62 & $9.33 \pm 2.02$ & 18.49 & 0.005 & $27.77 \pm 3.61$ & 21.83 & 0.367 & $16.45 \pm 4.29$ & 83.196 & $<0.001$ \\
\hline Medics & 107 & $7.38 \pm 3.00$ & & & $26.22 \pm 3.33$ & & & $10.74 \pm 3.69$ & & \\
\hline \multicolumn{11}{|l|}{ Age(Year) } \\
\hline $21-22$ & 62 & $9.18 \pm 2.02$ & 8.453 & $0.008 *$ & $27.66 \pm 3.62$ & 9.476 & $<0.001$ & $16.39 \pm 4.55$ & 39.298 & $0.001 *$ \\
\hline $23-24$ & 93 & $7.45 \pm 3.01$ & & & $25.19 \pm 3.26$ & & & $10.72 \pm 3.51$ & & \\
\hline $24-26$ & 14 & $7.14 \pm 3.15$ & & & $26.15 \pm 4.11$ & & & $11.14 \pm 4.11$ & & \\
\hline \multicolumn{11}{|l|}{ Gender } \\
\hline Male & 51 & $8.73 \pm 2.90$ & 4.150 & 0.303 & $25.57 \pm 3.44$ & 1.90 & 0.170 & $12.59 \pm 5.10$ & 0.192 & 0.662 \\
\hline Female & 118 & $7.77 \pm 2.75$ & & & $26.40 \pm 3.71$ & & & $12.94 \pm 4.67$ & & \\
\hline
\end{tabular}

Student t-test; *One-way ANOVA

Table 3: Showing the Participants' Practice towards PG

\begin{tabular}{|c|c|c|c|c|c|c|}
\hline \multirow{2}{*}{\multicolumn{2}{|c|}{ Statement }} & \multicolumn{4}{|c|}{ Final Year Medical Students } & \multirow[b]{2}{*}{$\begin{array}{l}\text { Never } \\
\text { N }(\%)\end{array}$} \\
\hline & & Always & $\begin{array}{l}\text { At least once in } \\
\text { one month } \\
N(\%)\end{array}$ & $\begin{array}{l}\text { At least once in } \\
\text { a semester } \\
N(\%)\end{array}$ & $\begin{array}{l}\text { At least once in the } \\
\text { program } \\
\mathrm{N}(\%)\end{array}$ & \\
\hline 1 & I do ask information about ADRs & $25(23.36)$ & $28(26.17)$ & $26(24.30)$ & $21(19.63)$ & $7(6.54)$ \\
\hline 2 & I related genetic variation to ADRs. & $1(0.93)$ & $8(7.48)$ & $20(18.69)$ & $27(25.23)$ & $51(47.66)$ \\
\hline 3 & $\begin{array}{l}\text { I attended lecture that is associated with effects of genetic } \\
\text { variations on drug therapy }\end{array}$ & $4(3.73)$ & $8(7.48)$ & $23(21.50)$ & $26(24.30)$ & $46(42.99)$ \\
\hline 4 & $\begin{array}{l}\text { I employed the idea of human genetic variation when } \\
\text { trying to solve a given drug-related case study questions }\end{array}$ & $1(0.93)$ & $2(1.87)$ & 14(13.08) & $16(14.95)$ & $74(69.16)$ \\
\hline \multirow[t]{2}{*}{5} & $\begin{array}{l}\text { I update my knowledge on genetic information in relation } \\
\text { to drugs }\end{array}$ & $1(0.93)$ & $7(6.54)$ & 21(19.63) & $29(27.10)$ & $49(45.79)$ \\
\hline & & Final year & macy students & & & \\
\hline 1 & I do ask information about ADRs & $38(61.29)$ & $15(24.19)$ & $7(11.29)$ & $2(3.23)$ & $0(0.0)$ \\
\hline 2 & I related genetic variation to ADRs & $7(11.29)$ & $20(32.26)$ & $18(29.03)$ & $12(19.35)$ & $5(8.06)$ \\
\hline 3 & $\begin{array}{l}\text { I attended lecture that is associated with effects of genetic } \\
\text { variations on drug therapy }\end{array}$ & $30(48.39)$ & $4(6.45)$ & $14(22.58)$ & $9(14.52)$ & $5(8.06)$ \\
\hline 4 & $\begin{array}{l}\text { I employed the idea of human genetic variation when } \\
\text { trying to solve a given drug-related case study questions }\end{array}$ & $10(16.13)$ & $5(8.06)$ & $8(12.90)$ & $15(24.19)$ & $24(38.71)$ \\
\hline 5 & $\begin{array}{l}\text { I update my knowledge on genetic information in relation } \\
\text { to drugs }\end{array}$ & $7(11.29)$ & $13(20.97)$ & $9(14.35)$ & $21(33.87)$ & $12(19.35)$ \\
\hline
\end{tabular}

"The illustration of the association between knowledge and practice, knowledge and attitudes, and attitude and practice of PG of drug safety among respondents (Table 4)": There is strong statistic association between knowledge and attitude of PG among respondents as evident with $\mathrm{p}=0.008$ at $95 \%$ confident interval. Similarly, a statistical significant was observed between knowledge and practice $(\mathrm{p}=0.018)$, and very same to the association between attitude and practice $(\mathrm{p}=0.009)$ at $95 \% \mathrm{CI}$. One hundred and two respondents $(60.36 \%)$ have mean knowledge score of more than $50 \%$, with and were considered average to above average considering that $50 \%$ is most commonly used pass mark in both medical and pharmacy schools. All of the respondents that have high knowledge scores also demonstrated excellent attitude $(60.36 \%)$. For the attitude scores, $99.4 \%$ of the respondents showed good to the excellent attitude with mean attitude score of $50 \%$ to $100 \%$. Out of $168(94.40 \%)$ respondents, only $82(48.81 \%)$ have shown average level of practice. More than half $(51.20 \%)$ of the respondents have shown a low level of practice, with mean percentage scores of less than $50 \%$ despite the excellent attitude and good knowledge of PG. 
Table 4: The Association Between KAP of the Respondents Using Chi-Square Test of Statistics.

\begin{tabular}{|c|c|c|c|c|c|c|}
\hline \multicolumn{5}{|c|}{ Attitude Score } & \multicolumn{2}{|c|}{ Practice Scores } \\
\hline Variable & Less positive & More positive & $P$ value & Less Practice & More practice & $\mathrm{p}$ value \\
\hline Knowledge & $\mathrm{N}(\%)$ & $\mathrm{N}(\%)$ & & $\mathrm{N}(\%)$ & $\mathrm{N}(\%)$ & \\
\hline Scores $(<50 \%)$ & $1(2.0)$ & $48(98.0)$ & 0.008 & $31(63.3)$ & $18(36.7)$ & 0.040 \\
\hline Scores $(>50)$ & $0(0.0)$ & $120(100.0)$ & 0.290 & $55(45.8)$ & $65(54.2)$ & \\
\hline Attitude & & & & & & \\
\hline Less positive $(<50 \%)$ & - & - & - & $0(0.0)$ & $1(100)$ & 0.491 \\
\hline More positive $(>50 \%)$ & - & - & - & $86(51.2)$ & $82(48.8)$ & \\
\hline
\end{tabular}

\section{DISCUSSION}

Most of the respondents have shown high familiarity and understanding of PGs with excellent attitudes. The knowledge of PGs among the respondents varies with the course of study and Age, with statistically significant difference 0.005 and 0.008 respectively, similar findings were revealed with attitude. Despite the demonstrated good knowledge and positive attitude towards PG, only about one-third of the respondents felt comfortable to read PGs, with significant differences between the pharmacy and Medical students. The majority $(91.94 \%)$ of pharmacy students were exposed to some aspect of PGs, while about half (42.99\%) of medical students were not at exposed at all. Moreover, about eighty percent of pharmacy students update their PG knowledge at least once in the program, while only about half of medical students had never updated. Our findings revealed strong statistic association between knowledge and attitude of PG among respondents as evident with $\mathrm{p}=0.008$ at $95 \%$ confident interval. Similarly, a statistical significant was observed between knowledge and practice $(\mathrm{p}=0.018)$, and very same to the association between attitude and practice $(\mathrm{p}=0.009)$ at $95 \% \mathrm{CI}$. One hundred and two respondents $(60.36 \%)$ have mean knowledge score of more than $50 \%$, with and were considered average to above average considering that $50 \%$ is most commonly used pass mark in both medical and pharmacy schools. All of the respondents that have high knowledge scores also demonstrated excellent attitude $(60.36 \%)$. For the attitude scores, $99.4 \%$ of the respondents showed that PG is important, has benefits to patients and with mean attitude score of $50 \%$ to $100 \%$. Out of 168 $(94.40 \%)$ respondents, only $82(48.81 \%)$ have shown average level of practice. More than half $(51.20 \%)$ of the respondents have shown a low level of practice, with mean percentage scores of less than $50 \%$ despite the excellent attitude and good knowledge of PG.

Previous researches have demonstrated knowledge gap, good attitude and low practice towards PG among current Doctors and Pharmacists(Yau et al., 2015; Bakhouche and Slanař, 2012; Benzeroual et al., 2012; Bernhardt et al., 2012; Bonter et al., 2011; Stanek et al., 2012; Johansen Taber and Press, 2014; Yau et al., 2015b); Moreover, study conducted in Ukraine among Pharmacy students revealed similar results (Filiptsova et al., 2015). However, study carried out in Malaysia, have discovered that current healthcare practitioners have good knowledge, attitude and consider PG to be a relevant field of clinical practice, but with low adoption (Bannur et al., 2014), and other studies have demonstrated healthcare students agree that PG is critical to patient care (Drozda et al., 2013; Gurwitz et al., 2005; McCullough et al., 2011; Moen and Lamba, 2013). Although about half of the participants have never attended lectures related to PG, a good knowledge and attitude was reported, and this could be related to advancement in technology and social media or News feeds especially when the President Barack Obama of USA talked about precision Medical at the White House to the media (The White House, 2015). The significant differences observed in KAP towards PG, could be related to the fact that PG is more of pharmacy profession than of medicine profession. Moreover, the pharmacy profession has been mainly drug and patients oriented field while medicine profession has been mostly diagnostics, surgery and patients oriented.

The low level of practice observed among both pharmacy and medical students might be related to the fact that PG is a relatively new field of study and also PG is not yet seen as an essential tool in drug safety, therefore not an important component of routine medical practice. Furthermore, it might be due to the wrong assumption that less has been known about the clinical evidence and guidelines on PG, which could facilitate their mentors to expose them to it. More in depth prospective studies are advocated to produce highly professional and devoted health professionals (Islam et al., 2014a; Salam et al. 2013a; Salam et al. 2013b; Salam et al. 2013c).

\section{CONCLUSION}

Majority of participated Malaysian future Doctors \& Pharmacists demonstrated good knowledge and attitude towards PG. Researches are required with large sample to investigate the barriers to the application of PG into practice. The curriculum should be revisited especially that of medical schools.

\section{REFERENCES}

Bakhouche H, Slanař O. Pharmacogenetics in clinical practice. Prague Med Rep, 2012; 113: 251-61. doi:10.2217/pme.12.80.

Bannur Z, Bahamas S, Salleh MZ, Teh LK. Pharmacogenomics Based Practice in Malaysia: The Attitude, Knowledge and Adoption by the Healthcare Professionals. IMJM, 2014;13: 41-50.

Benzeroual KE, Shah B, Shinde S. Pharmacogenomics: assessing educational exposure, confidence in knowledge and training elements of pharmacists. Per Med, 2012; 9: 387-393.

Bernhardt BA, Zayac C, Gordon ES, Wawak L, Pyeritz RE, Gollust SE. Incorporating direct-to-consumer genomic information into patient care: attitudes and experiences of primary care physicians. Per Med, 2012; 9: 683-692. 
Bonter K, Desjardins C, Currier N, Pun J, Ashbury FD. Personalized medicine in Canada: a survey of adoption and practice in oncology, cardiology and family medicine. BMJ Open, 2011; 1: e000110

Charan J, Biswas T. How to Calculate Sample Size for Different Study Designs in Medical Research? Indian J Psychol Med, 2013; 35: 121 126.

de Denus S, Letarte N, Hurlimann T, Lambert J-P, Lavoie A, Robb L, Sheehan NL, Turgeon J, Vadnais B. An evaluation of pharmacists' expectations towards pharmacogenomics. Pharmacogenomics, 2013;14: 165-175.

Drozda K, Labinov Y, Jiang R, Thomas MR, Wong SS, Patel S, Nutescu EA, Cavallari LH. A pharmacogenetics service experience for pharmacy students, residents, and fellows. Am J Pharm Educ, 2013;77: 175.

Field A. Discovering Statistics Using SPSS. 3rd Edition. Sage Publications Ltd, London. 2009

Filiptsova OV, Kobets MN, Kobets YN. Some aspects of genetics and pharmacogenetics understanding by pharmacy students in Ukraine. Egypt J Med Hum Genet, 2015;16: 61-66.

Gurwitz D, Lunshof JE, Dedoussis G, Flordellis CS, Fuhr U, Kirchheiner J, Licinio J, Llerena A, Manolopoulos VG, Sheffield LJ, Siest G, Torricelli F, Vasiliou V, Wong S. Pharmacogenomics education: International Society of Pharmacogenomics recommendations for medical, pharmaceutical, and health schools deans of education. Pharmacogenomics J, 2005; 5: 221-225.

Hinton P. Statistics explained. Revised ed. Cambridge. Routledge, London and New York. 2014

Islam MZ, Salam A, Helali AM , Rahman Z, Dali WPEW, Ismail S , Rahman NIA, Haque M. Comparative Study of Professionalism of Future Medical Doctors Between Malaysia and Bangladesh. J App Pharm Sci, 2014a; 4: 066-071.

Islam MZ, Rahman MF, Mossaddek ASM, Rozario RJ, Iftekhar AFMH, Akhter S, Jahan I, AMH, Dali WPEW, Ismail S, Rahman NIA, Haque M. Bangladeshi Interns' Knowledge of Pharmacology and Therapeutics For Prescribing. J App Pharm Sci, 2014b; 4 (04): 043-051.

Jeetu G, Anusha G. Pharmacovigilance: a worldwide master key for drug safety monitoring. J Young Pharm, 2010; 2: 315-320.

Mccullough KB, Formea CM, Berg KD, Burzynski JA, Cunningham JL, Ou NN, Rudis MI, Stollings JL, Nicholson WT. Assessment of the pharmacogenomics educational needs of pharmacists. Am J Pharm Educ, 2011; 75: 51.

Moen M, Limba J. Assessment of healthcare students' views on pharmacogenomics at the University of Minnesota. Pharmacogenomics, 2013; 13: 1537-1545.

Pallant J. SPSS survival manual. McGraw-Hill Education (UK), 2013.

Sadee W. Genomics and personalized medicine. Int J Pharm, 2011; 415: 2-4

Salam A, Yousuf R, Islam MZ, Yesmin F, Helali AM, Alattaraqchi AG, Rao USM, Haque M. Professionalism of future medical professionals in Universiti Sultan Zainal Abidin, Malaysia. Bangladesh J Pharmacol, 2013a; 8: 124-130.
Salam A, Haque M, Helali AM, Islam MZ, Mohsena M, Rahman Z, Yesmin F, Rahman NIA, Alattaraqchi AG, Yousuf R. Comparative Study On Professionalism Of Forthcoming Medical Doctors Between Two Private Medical Colleges In Savar, Bangladesh. Int J Pharm Pharm Sci. 2013b; 59: 659-665.

Salam A, Haque M, Islam MZ, Helali AM, Yousuf R, Yesmin F, Alattaraqchi AG, Rao USM. Comparative Study of Professionalism of Future Medical Professionals among Three Private Medical Colleges of Bangladesh. Asian J Pharm Clin Res. 2013c; 6: 170-179.

Stanek EJ, Sanders CL, Johansen Taber KA, Khalid M, Patel A, Verbrugge R, Agatep BC, Aubert RE, Epstein RS, Frueh FW. Adoption of pharmacogenomic testing by US physicians: results of a nationwide survey. Clin Pharmacol Ther, 2012; 91: 450-458.

Steve M. Statistics explained. 1st Edition. Cambridge. London.

1998

Johansen Taber KA, Dickinson BD. Pharmacogenomic knowledge gaps and educational resource needs among physicians in selected specialties. Pharmgenomics Pers Med, 2014; 7: 145-162.

The White House. Fact Sheet: President Obama's Precision Medicine Initiative. 2015. Available from: https://www.whitehouse.gov/the-press-office/2015/01/30/fact-sheet-

president-obama-s-precision-medicine-initiative [Accessed on 27-122015]

World Health Organization (WHO). The Importance Of Pharmacovigilance: Monitoring, Safety. Uppsala World Health Organization, United Kingdom. 2002. Available from: http://apps.who.int/medicinedocs/pdf/s4893e/s4893e.pdf [Access ed on 27-12-2015]

Yau A, Aziz ABA, Haque M. Knowledge, Attitude and Practice Concerning Pharmacogenomics among Pharmacists: A Systematic Review. J Young Pharmacists, 2015a; 7: 145-154.

Yau A, Husain R, Aziz ABA, Johari MKBM, Rahman AFB, Elkalmi RM, Jamilu Y, Haque M. Psychometric Properties of Knowledge, Attitude, and Practice on Pharmacogenovigilance in Drug Safety Questionnaire in Medical and Pharmacy Students: based on Exploratory Factor Analysis. J Appl Phar Sci, 2015; 5 (11): 15-22.

Yau A, Husain R, Haque M. A Systematic Review of Knowledge, Attitude and Practice towards Pharmacogenomics among Doctors. Int J Pharm Res, 2015c; 7: 9-16.

\section{How to cite this article:}

Yau A, Haque M. Pharmacogenomics: Knowledge, Attitude and Practice among Future Doctors and Pharmacists - A Pilot Study. J App Pharm Sci, 2016; 6 (02): 141-145. 